\title{
BEBAN KERJA DAN TINGKAT PENGANGGURAN PEREMPUAN USIA PRODUKTIF DI DESA TRIMULYA SP II
}

\author{
Agus Wartiningsih \\ Prodi Pendidikan Bahasa dan Sastra Indonesia, FKIP Untan, Pontianak \\ Email: aguswartiningsigfkip@gmail.com
}

\begin{abstract}
Abstrak
Kesetaraan gender yang selama ini diperjuangkan oleh banyak tokoh perempuan di negeri ini bahkan di dunia, ternyata tidak serta merta menjadikan perempuan hidup lebih layak jika dilihat dari segi mendapatkan pekerjaan yang layak. Banyak hal yang dijadikan alasan oleh banyak pihak untuk tidak memberikan kesempatan perempuan bekerja di luar rumah. Beberapa alasan untuk tidak menjadikan perempuan bekerja di luar rumah adalah: 1) rendahnya tingkat pendidikan kaum perempuan, hingga tidak layak untuk bekerja di bidang tertentu; 2) adanya kekhawatiran banyak pihak bahwa perempuan yang bekerja di luar rumah akan meninggalkan pekerjaan rumah sebagai ibu dan sebagai istri; 3) kurangnya pengalaman perempuan bekerja di luar rumah, sehingga dikhawatirkan perempuan tidak dapat mengerjakan pekerjaannya dengan baik; dan 4) adanya anggapan bahwa perempuan itu lemah, sehingga dikhawatirkan tidak mampu mengerjakan pekerjaan-pekerjaan berat. Tujuan penelitian ini adalah pendeskripsian tingkat beban kerja dan tingginya tingkat pengangguran yang dialami perempuan usia produktif di Desa Trimulya SP II Kecamatan Mukok Kabupaten Sanggau akibat rendahnya pendidikan. Metode yang digunakan dalam penelitian ini metode deskriptif, bentuk penelitian kualitatif, dengan instrumen penelitian peneliti sendiri. Teknik penelitian yang digunakan teknik observasi dan dokumenter, sumber data dokumen desa, data penelitian berupa tingkat pendidikan dan jumlah pengangguran. Hasil penelitian ini adalah rendahnya tingkat pendidikan menyebabkan tingginya tingkat beban kerja dan tingkat pengangguran yang dialami perempuan di Desa Trimulya Kecamatan Mukok Kabupaten Sanggau.
\end{abstract}

\section{Kata kunci: Beban Kerja, Pengangguran, Perempuan}

\section{PENDAHULUAN}

Istilah gender telah digunakan sejak awal 1970-an untuk menunjukkan feminitas dan maskulinitas yang dibentuk oleh budaya sebagai sesuatu yang berlawanan dengan perbedaan jenis kelamin secara biologis (sex). Dengan demikian untuk memahami konsep gender, harus dibedakan antara gender dan seks (jenis kelamin). "Gender merupakan behavioral differences (perbedaan perilaku) yang bukan ketentuan Tuhan adalah sifat yang melekat pada kaum laki-laki maupun perempuan yang dikonstruksi secara sosial maupun kultural dan diciptakan oleh manu-sia." (Fakih, 2010: xii).

Sedangkan jenis kelamin (sex) adalah perbedaan biologis yang bersifat kodrati dari Tuhan bersifat permanen dan tidak dapat dipertukarkan. Dengan demikian "gender dapat berubah dari tempat ke tempat, dari waktu ke waktu, bahkan dari kelas ke kelas, sedangkan jenis kelamin biologis akan tetap tidak berubah." (Nugroho, 2008: 3).

Gagasan yang dikandung dalam teori gender adalah bahwa perbedaan antara lakilaki dan perempuan tidaklah melulu ditentukan oleh biologis - memiliki sejarah yang lebih panjang. Beauvoir (dalam Jackson dan Jones) menjelaskan bahwa "Seseorang tidak dilahirkan sebagai perem-puan, tetapi dibentuk menjadi perempuan". Anggapan bahwa perempuan dibentuk dan bukan dilahirkan telah menjadi pusat perhatian dalam teori gender. Ciri lain dan sangat penting dari perspektif feminis adalah bahwa "gender dirumuskan secara hierarkis: kita tidak berhadapan dengan perbedaan simetris 
antara laki-laki dan perempuan, namun dengan hubungan tidak simetris dan tidak setara". (Jackson dan Jones, 2009)

"Salah satu faktor yang mempengaruhi adanya kesenjangan gender adalah bermacammacamnya tafsiran tentang pengertian gender. (Nugroho, 2008: 1). Setidak-tidaknya ada beberapa penyebab terjadinya ketidakjelasan dan kesalahpahaman gender. Penyebab terjadinya ketidakjelasan dan kesalahpahaman istilah gender tersebut adalah terjadinya kesalahpahaman antara makna gender dan seks, antara kodrat dan budaya, antara laki-laki dan perempuan.

Pemahaman yang salah terhadap pengertian gender dari semenjak dulu hingga saat ini sebagai penyebab utama terjadinya ketidaksetaraan dan bahkan mengacu pada kekerasan dan ketidakadilan yang dialami perempuan. Pendapat lainnya berkaitan dengan gender disampaikan Homzah (2010: 3) sebagai berikut. Penciptaan manusia oleh Tuhan tentunya sudah dengan perhitungan dan rencana yang paling tepat. Tuhan menciptakan umatnya tentu tidak ada yang salah dan pastinya penciptaan manusia sudah disertai dengan berbagai tugas, kebutuhan dan peran masing-masing setiap individu. Oleh karena itu, tidak ada manusia yang diciptakan Tuhan lebih baik dari pada yang lainnya, kecuali perbedaan ketaqwaan manusia itu sendiri kepada Tuhannya. Berlandas pada pemikiran tersebut, peneliti juga berpendapat bahwa terciptanya ma-nusia menjadi laki-laki atau perempuan adalah takdir dan kehendak Tuhan. Tidak ada yang dapat meminta dan menolak ketentuan Tuhan, jika Tuhan telah berke-hendak. Artinya, diciptakannya laki-laki atau perempuan tentunya karena di anta-ranya saling memerlukan. Hanya saja dalam kenyataannya penciptaan laki-laki dan perempuan oleh Tuhan telah disalahartikan oleh manusia. Perdebatan dan perbedaan perlakuan masyarakat kepada perempuan ini biasa disebut dengan istilah gender dan bias gender.

Terciptanya individu sebagai laki-laki berarti dengan segala kekuasaan, kekuatan, dan hak untuk mengatur perempuan. Sedangkan terciptanya individu sebagai perempuan maka ia telah menanggung beban menjadi individu yang lemah, hanya berada di rumah, menjadi istri, menjadi ibu dan segala urusan domestik rumah tang-ganya tanpa ada kata tidak mau atau menolak. Hal inilah yang hingga saat ini menjadi masalah bagi kaum perempuan dan melahirkan gerakan perempuan dengan istilah feminisme. Perjuangan feminisme membawa angin segar bagi keadilan dan pembebasan perempuan dari berbagai ke-tertindasan yang selama ini dialami perempuan.

Perbedaan gender telah melahirkan berbagai ketidakadilan, baik bagi ka $\neg$ um laki-laki dan terutama terhadap kaum perempuan seperti yang disampaikan oleh Fakih (2010: 12-13).

Ketidakadilan gender ini telah terjadi di berbagai aspek kehidupan perempuan, yakni: marginalisasi atau proses pemiskinan ekonomi, subordinasi atau anggapan tidak penting dalam kepu $\neg$ tusan politik, pemben-tukan strereotipe atau melalui pelabelan negatif, kekerasan (violence), beban kerja lebih panjang dan lebih banyak (burden) serta sosialisasi ideologi nilai peran gender.

Berikut ini dijelaskan berbagai bentuk ketidakadilan yang disebabkan oleh per-bedaan gender berdasarkan teori tersebut.

\section{Gender dan Marginalisasi Perempuan}

Marginalisasi yang mengakibatkan kemiskinan dapat terjadi karena berbagai sebab. Penyebab marginalisasi atau kemiskinan ini di antaranya adalah karena penggusuran, bencana alam atau proses eksploitasi. Selain penyebab tersebut, ada juga penyebab lain yang mengakibatkan terjadinya marginalisasi atau kemiskinan yaitu yang disebabkan oleh gender. Bentuk marginalisasi atau kemiskinan yang dia-kibatkan oleh gender ini beraneka ragam bergantung dari sumbernya, keyakinan, atau asumsi. Marginalisasi yang berasal dari sumbernya misalnya dari sebuah kebijakan pemerintah, keyakinan, tafsiran agama, keyakinan tradisi dan kebiasaan atau bahkan asumsi ilmu pengetahuan.

Marginalisasi kaum perempuan tidak saja terjadi di tempat pekerjaan, juga terjadi dalam rumah tangga, masyarakat atau kultur dan bahkan negara. Marginalisasi terhadap perempuan sudah terjadi sejak di rumah tangga dalam bentuk diskriminasi atas anggota keluarga yang laki-laki 
dan perempuan. Marginalisasi juga diperkuat oleh adat istiadat maupun tafsir keagamaan. (Fakih, 2010: 14-15).

\section{Gender dan Subordinasi}

Pandangan terhadap perbedaan gender lainnya yang dapat melahirkan keti-dakadilan adalah subordinasi terhadap perempuan. Subordinasi yang dimaksud dalam rencana penelitian ini adalah bentuk subordinasi yang beranggapan bahwa perempuan itu irrasional atau emosional. Sifat irasional atau emosional perempuan mengakibatkan perempuan tidak dapat tampil menjadi seorang pemimpin. Keadaan tersebut mengakibatkan perempuan tidak dapat menempati tempat penting di sebuah pemerintahan.

Subordinasi atau anggapan bahwa perempuan irrasional atau emosional sehingga tidak dapat menempati posisi penting dalam pemerintahan telah terjadi sejak dahulu dari waktu ke waktu dan di semua tempat (Fakih 2010: 15-16 dan Nugroho, 2008: 11-12). Bahkan di Jawa ada anggapan bahwa perempuan tidak perlu sekolah tinggi-tinggi, toh akhirnya akan ke dapur juga. Bahkan, pemerintah pernah memiliki peraturan bahwa jika suami akan pergi belajar (jauh dari keluarga) dia bisa mengambil keputusan sendiri. Sedangkan bagi istri yang hendak tugas belajar ke luar negeri harus seijin sua-mi." (Fakih 2010: 15-16 dan Nugroho, 2008: 16).

Subordinasi terhadap perempuan ini tidak hanya terjadi pada perempuan dewasa atau ibu rumah tangga saja. Akan tetapi subordinasi juga terjadi pada anak-anak perempuan. Hal ini terjadi apabila keuangan keluarga tidak mencukupi maka yang boleh melajutkan sekolah adalah anak-laki-laki. Dengan demikian praktik-praktik subordinasi terhadap perempuan telah terjadi sejak anak perempuan dalam usia dini sekalipun. Hal tersebut me-nunjukkan ketidakadilan yang berangkat dari pandangan gender yang tidak benar.

\section{Gender dan Stereotipe}

Ketidakadilan lainnya yang diaki-batkan oleh perbedaan gender adalah strereotipe. Stereotipe adalah pelabel $\neg$ an atau penandaan terhadap suatu kelompok tertentu. Jenis pelabelan atau penandaan yang dimaksud misalnya saja, kalau perempuan berdandan atau bersolek maka perempuan tersebut memiliki tujuan untuk memancing perhatian laki-laki. Laki-laki yang tertarik pada perempuan yang cantik karena perempuan itu berdandan atau ber-solek kemudian melakukan tindak keke-rasan berupa pelecehan seksual atau sampai tingkat pemerkosaan ma $\neg$ ka pihak yang salah adalah perempuan. (Fakih, 2010: 16-17).

Pelimpahan kesalahan pada perem-puan yang menyebabkan terjadinya pelecehan seksual atau sampai pada tingkat pemerkosaan bukan tanpa alasan oleh masyarakat. Hal tersebut justru berdasar pada budaya, peraturan pemerintah, kebiasaan masyarakat, bahkan aturan keagamaan yang terdapat dalam masyarakat yang mengharuskan perempuan atau tugas utama perempuan adalah di rumah dan melayani suami. Hal itu terjadi karena adanya kesalahan dalam memahami konsep gender di masyarakat.

\section{Gender dan Kekerasan}

Kekerasan atau violence adalah serangan atau invasi (assault) terhadap fisisk maupun integritas mental psikologi seseorang. (Fakih, 2010: 17). Bentuk kekerasan yang disebabkan oleh bias gender ini biasanya disebut genderrelatet violence. Bentuk-bentuk kekerasan yang terjadi dalam masyarakat terutama yang dialami perempuan adalah bentuk dari ketidaksetaraan kekuatan itu sendiri.

Secara umum bentuk kekerasan terhadap perempuan dapat dibedakan ke dalam 10 kelompok kekerasan. Bentuk kekerasan yang dimaksud adalah: 1) kekerasan terhadap perempuan dalam perspektif gender, 2) kekerasan terhadap perempuan dalam perspektif ekonomi, 3) kekerasan terhadap perempuan dalam per-spektif sosiologi, 4) kekerasan terhadap perempuan dalam perspektif antropologi, 5) kekerasan terhadap perempuan dalam perspektif psikologi, 6) kekerasan terhadap perempuan dalam perspektif ilmu hukum, 7) kekerasan terhadap perempuan dalam perspektif media massa, 8) kekerasan terhadap perempuan dalam perspektif perspektif agama, 9) modus operandi trafiking sebagai salah satu bentuk kekerasan terhadap perempuan, dan 
10) kekerasan terha $\neg$ dap perempuan: sebuah refleksi." (Sulaeman dan Homzah, 2010: IX-X).

\section{Gender dan Beban Kerja}

Bentuk kekerasan akibat perbedaan gender selanjutnya adalah kekerasan dalam hal beban kerja. "Anggapan bahwa perempuan memiliki sifat memelihara dan rajin, akibatnya semua tugas domestik harus dilakukan oleh perempuan." (Fakih, 2010: 17-21). Dengan demikian perempuan harus bekerja dalam waktu yang lama dengan pekerjaan yang bayak. Keadaan ini tidak terkecuali untuk perempuan yang bekerja di luar rumah. Bagi perempuan yang bekerja di luar rumah maka pekerjaan perempuan semakin bertambah. Selain bekerja di luar, perempuan juga harus menyelesaikan perkerjaan rumah tanpa dibantu oleh laki-laki. Itu artinya beban kerja perempuan melebihi jumlah beban kerja lakilaki. Hal tersebut juga termasuk dalam bentuk kekerasan yang diakibatkan oleh perbedaan gender.

Hal tersebut sesuai pendapat Saptari dan Holzner bahwa "Pembagian kerja seksual adalah pembagian kerja yang didasarkan atas jenis kelamin. Di kebanyakan masyarakat ada pembagian kerja seksual di mana beberapa tugas dilaksanakan oleh perempuan dan beberapa tugas lain semata-mata dilakukan oleh laki-laki." (Sapari dan Holzner: 21). Pembagian kerja berdasarkan gender juga disampaikan oleh Nugroho bahwa "Pem-bagian kerja berdasarkan gender mengacu pada pekerjaan yang berbeda yang dilaku-kan oleh perempuan dan laki-laki sebagai konsekwensi dari pola-pola sosialisasi mereka, tugas-tugas yang secara tradisional diidentifikasikan dilihat sebagai 'kerja perempuan' dan 'kerja laki-laki'." (Nugroho, 2008: 238).

\section{Pengangguran}

Kata pengangguran berasal dari kata "anggur atau menganggur" yang artinya tidak melakukan apa-apa: tidak bekerja. Pengangguran sendiri diartikan sebagai hal atau keadaan menganggur, atau secara terbuka pengangguran yang ditunjukkan oleh adanya jumlah penganggur yang nyata (yang mudah dilihat dan dapat dihitung). Berdasarkan pada teori tarsebut maka yang dimaksud dengan jumlah pengangguran perempuan usia produktif di SP II Kecmatan Mukok Kabupaten Sanggau adalah sejumlah perempuan yang secara kasat mata diketahui tidak bekerja atau tidak Malakukan aktivitas bekerja untuk mencari nafkah. Jumlah pengangguran perempuan dimaksud berdasarkan hasil pengamatan sementara dianggap cukup tinggi. Hal inilah yang mendorong peneliti ingin mengetahui faktor apa yang sangat menentukan terjadinya tingkat peng-angguran yang sangat tinggi yang dialami perempuan usia produktif di SP II Kecamatan Mukok Kabupaten Sanggau.

\section{Perempuan}

Penggunaan diksi perempuan dalam penelitian ini berdasar pada beberapa alasan, di antaranya adalah: 1) dari beberapa literatur yang memuat teori perempuan lebih menggunakan istilah perempuan daripada wanita; 2) istilah perempuan bila dilihat dari asal kata dianggap lebih mewakili ide yang menjadi tujuan peneltian yaitu "Perempuan berasal dari kata $p u$ kempudian три lalu етри yang juga berarti 'tuan', 'orang yang dihormati', atau 'ahli dalam suatu ebidang'. Kemudian juga berarti 'pemilik' kemudian 'orang yang dimiliki'. Dalam bahasa Malaysia dipergunakan kata puan sebagai antonim dari tuan." (Keraf, 2009: 55). Sedangkan "Wanita dihi $\neg$ potesiskan bersumber dari kosakata bahasa Sansekerta, yaitu vanita yang berarti yang diinginkan (oleh kaum pria)." (Budiman dalam Murniati, 2004: 4-5).

Dalam budaya patriarkhat, "Simbol perempuan adalah nature (alam), simbol laki-laki adalah culture (budaya), maka dalam perjalanan sejarah terjadi perlakuan culture terhadap nature." (Cormack dalam Murniati, 2004: 211). Teori tersebut juga lebih berpihak pada kaum laki-laki yang memiliki kekuasaan dan kewenangan untuk mengatur perempuan.

\section{Usia Produktif}

Usia produktif berasal dari dua kata dasar yaitu usia dan produktif. Usia diartikan sebagai umur sedangkan pro-duktif diartikan sebagai usia ke $\neg$ tika seseorang masih mampu bekerja dan menghasilkan sesuatu. Berdasarkan arti dari dua 
kata dasar tersebut dapat dimaknai bahwa yang dimaksud usia produktif adalah usia seseorang yang dianggap dapat melakukan pekerjaan tertentu untuk men-dapatkan penghasilan guna memenuhi kebutuhan hidup pribadinya dan juga kekluarganya.

\section{Desa Trimulya SP II Kecamatan Mukok Kabupaten Sanggau}

Desa Trimulya merupakan nama de $\neg$ sa yang terletak di SP II Kecamatan Mukok Kabupaten Sanggau. Desa Trimula merupakan satu di antara empat desa lainnya di Kecamatan Mukok. Desa Trimulya terdiri dari lima dusun yaitu dusun Tokang Jaya, dusun Tokang Baru, dusun Bakong Jaya, dusun Marga Mulya, dusun Marga Jaya, dan dusun Manunggal Jaya. Jumlah penduduk Desa Trimulya 2529, dengan rincian jumlah laki-laki 1266 jiwa, dan jumlah perempuan 1263 jiwa. Berikut ini juga ditampilkan peta desa Trimulya.

\section{METODOLOGI PENELITIAN}

Metode dalam penelitian ini metode deskriptif dengan bentuk penelitian kualitatif, dengan instrumen penelitian peneliti sendiri. Teknik penelitian yang digunakan teknik observasi dan dokumenter, sumber data dokumen desa, data penelitian berupa tingkat pendidikan dan jumlah pengangguran.

\section{HASIL PENELITIAN DAN PEMBAHASAN}

Berdasarkan hasil analisis data ten-tang jenis pekerjaan, dapat dimaknai bahwa rendahnya tingkat Pedidikan perempuan yang terdapat di Desa Trimulya Kecamatan Mukok Kabupaten Sangga yang terdiri dari 6 dusun tercatat jumlah perempuan dengan beban kerja yang berat sangat tinggi. Dengan demikian, dapatlah dikatakan bahwa rendahnya tingkat pendidikan yang dialami perempuan menjadi penyebab uta-ma beratnya beban kerja yang ditanggung perempuan. Hal tersebut terlihat merata bahwa untuk di setiap dusun yang ada di Desa Trimulya jumlah perempuan yang bekerja di bidang yang tidak sesuai terhitung sangat tinggi yaitu 376 dengan berbagai jenis pekerjaan dari jumlah keseluruhan perempuan berjumlah 1.123 orang.
Hal tersebut masih akan gerabah dengan jumlah perempuan yang tidak memiliki pekerjaan akibat rendahnya tingkat pendidikan mereka.

Berdasarkan analisis data jenis pekerjaan masyarakat Desa Trimulya Kecamatan Mukok Kabupaten Sanggau tersebut, dapat dikamnai bahwa rendahnya tingkat pendi-dikan perempuan yang terapat di Desa Trimulya Kecamatan Mukok Kabupaten Sanggau yang terdiri dari 6 dusun tercatat jumlah perempuan yang tidak memiliki pe-kerjaan sangat tinggi, yaitu 594 dibanding lakilaki hanya 319 orang. Dengan demikian, dapatlah dikatakan bahwa rendahnya tingkat pendidikan yang dialami perempuan menjadi penyebab utama tingginya tingkat pengangguaran. Hal terse-but terlihat mmerata bahwa untuk di setiap dusun yang ada di Desa Trimulya jumlah pengangguran perempuan lebih tinggi dibanding laki-laki.

\section{SIMPULAN DAN SARAN}

\section{Simpulan}

Rendahnya tingkat pendidikan yang dialami perempuan di Desa Trimulya Kecamatan Mukok Kabupaten Sanggau menjadi penyebab utama tinnginya beban kerja yang harus dialami perempuan. Jenis pekerjaan yang harus dilakukan oleh para perempuan adalah: bertani, menjadi buruh tani, berjualan keliling, pengrajin industri, dan menjadi buruh perkebunan kelapa sawit dan pabrik. Rendahnya tingkat pendidikan yang dialami perempuan di Desa Trimulya Kecamatan Mukok Kabupaten Sanggau menjadi penyebab utama tinnginya tingkat pengangguran yang dialami perempuan karena tidak memiliki kualifikasi untuk bekerja di bidang yang lebih tepat.

\section{Saran}

Kepada para orang tua khususnya para perempuan yang saat ini tidak mungkin lagi untuk meneruskan pendidikan, hendaknya tidak menjadi penghalang bagi anak-anak perempuannya yang hendak melanjutkan pendidikan hingga ke perguruan tinggi. Kepada para perempuan yang saat ini masih dalam masa pendidikan hendaknya dapat menyelesaikan pendidikan hingga ke jenjang tertinggi agar mendapatkan pekerja-an 
yang layak dan mengurangi jumlah pengangguran kaum perempuan. Kepada pihak-pihak terkait hedaknya tidak mendeskriminatifkan perempuan untuk selalu menjadi yang terbelakang dan terberat menanggung beban pekerjaan.

\section{DAFTAR PUSTAKA}

Fakih, Mansour. 2010. Analisis Gender dan Transformasi Sosial. Yogyakarta: Pustaka Pelajar.

Homzah, Siti. 2010. Kekerasan terhadap Perempuan. Bandung: Refika Aditama.

Jackson, Stevi dan Jackie Jones. 2009. Pengantar
Teori-Teori Feminis Kontemporer.

Yogyakarta: Jalasutra.

Keraf, Gorys. 2009. Diksi dan Gaya Bahasa. Jakarta: Garamedia Pustaka Utama.

Murniati, A. Nunuk P. 2004. Getar Gender: Perempuan Indonesia dalam Perspektif Sosial, Politik, Ekonomi, Hukum dan HAM. Magelang: Yayasan Indonesia Tera.

Nugroho, Rian. 2008. Gender dan Strategi Pengarus-Utamanya di Indonesia. Yogyakarta: Pustaka Pelajar.

Sapari, Ratna dan Brigitte Holzner (Tanpa Tahun). Perempuan Kerja dan Perubahan Sosial. Jakarta: Yayasan Kalyanamitra. 